Food, Dairy and Home Economic Research

Available online at http://zjar.journals.ekb.eg

http:/www.journals.zu.edu.eg/journalDisplay.aspx?.Journalld=1\&queryType=Master

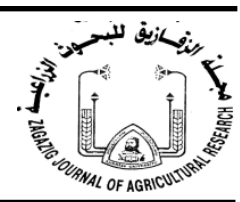

\title{
QUALITY ASSESSMENT OF YOGURT ENRICHED WITH OAT AND CHICKPEA POWDERS AS SOURCE OF DIETARY FIBERS
}

\author{
Mohamed A-E.M. Elbahnasi ${ }^{1}$, A.H. Gerguis ${ }^{1}$, A.A. Abd El Galeel ${ }^{1}$, A.S. El-Zoghaby ${ }^{2}$ \\ 1. Food Sci. Dept., Fac. Agric., Zagazig Univ., Egypt \\ 2. Anim. Prod. Res. Inst., Agric. Res. Cent., Dokki, Egypt
}

\section{Received: 02/06/2021 ; Accepted: 15/09/2021}

\begin{abstract}
The aim of this study was to evaluate the effect of addition of oat and chickpea powders on the rheological, physicochemical and sensory characteristics of yogurt. Yogurt was fortified with oat and chickpea powders at ratios of 1,2 and 3\% of each. Yogurt was stored at $5 \pm 2^{\circ} \mathrm{C}$ and analyzed when fresh and after 5, 10 and 15 days of storage. Results showed that: Control yogurt had the lowest total solids (TS), fat, protein, ash and fibers contents compared with fortified yogurt treatments. The TS, fat ,protein, ash and fibers contents of yogurt containing oat and chickpea powders at different concentrations increased gradually by increasing the percentage added, Addition of oat and chickpea powders at different concentrations increased the $\mathrm{pH}$ in yogurt. Whereas, titratable acidity decreased with increased fortification ratio. Fortification of yogurt with oat and chickpea powders at different concentrations significantly decreased whey syneresis and increased viscosity compared with control yogurt and this increasing was proportional to the fortification ratio. Addition of oat and chickpea powders at different concentrations significantly increased phenolic contents and antioxidant activity of yogurt treatments and these increments were proportional to the fortification ratio. Yogurt treatments fortified with oat and chickpea powders at different concentrations had the lowest counts of total bacteria, yeast and moulds,Streptococcus salivarius subsp. thermophilus and Lactobacillus delbruekii subsp. bulgaricuscounts. Total bacteria, yeast and moulds,Streptococcus salivarius subsp. thermophilus and Lactobacillus delbruekii subsp. bulgaricuscounts decreased with increasing the fortification ratio. Control yogurt had the lowest sensory evaluations values. Addition of oat and chickpea powders improved the organoleptic properties of fortified yogurt; the highest mean value was related to sample containing $3 \%$ oat powder.
\end{abstract}

Key words: Yogurt, oat, chickpea powders, dietary fibers.

\section{INTRODUCTION}

Yogurt is one of the most consumed healthy and nutritious foodstuff worldwide (Shi et al., 2017; Zhiet al., 2018). Yogurt has a better digestibility of proteins than milk and many latent positive effects on health by providing the human body prebiotic and probiotic bacteria. Additionally, by incorporating fibers in yogurt, researchers have achieved a mean of increased fibers consumption in all sectors of the populace and they have developed a functional food with an extensive array of beneficial effects. Several

\footnotetext{
* Corresponding author: Tel. :+201099118692

E-mail address: mohamedelbahnasi5@gmail.com
}

studies reported prebiotic fortification by adding dietary fibers in yogurt. Consumption of high fiber yogurt may prevent or reduce obesity, diabetes, cancer, hypercholesterolemia, gastrointestinal disorders, colonic diverticulosis and constipation, ulcerative colitis, hyperlipidemia, hypertension, coronary artery disease, but also promote intestinal microflora and gastrointestinal immunity (Delloet al, 2017; Tomicet al., 2017).

Since it is known that a lack of fibers in the diet can be the cause of many nutritionassociated illnesses, the European Food Safety Authority (EFSA) has been forced to recommend 
an average daily fibers intake of $25 \mathrm{~g}$ (EFSA, 2010). Fibers are found in the cell wall of vegetables, fruits or cereals. They include polysaccharides (pectins, cellulose and hemicelluloses) and lignin. Although both soluble and insoluble fibers are available, usually the insoluble fibers are used with food fortifying intents (Tejada-Ortigozaet al, 2016: Dönmezet al., 2017).

Many researchers reported that the rheological properties of yogurt are affected differently depending on the type of fiber source (Luana $\boldsymbol{e t}$ al., 2014; Raju and Pal, 2014). The role in increasing the water holding capacity, in stabilization of high fat yogurt, in enhancing viscosity characteristics the gel forming ability are properties of fibers that allow the development of fiber-enriched yogurt with improved texture and reduced syneresis (DelloStaffolo et al., 2017; Balthazar et al., 2016).

Oat (Avena sativa $\mathrm{L}$.) and oat products are a good sources of vitamin $E$, polyunsaturated fatty acids, soluble dietary fiber, $\beta$-glucan, and their consumption in the human diet is beneficial to human well-being (Tiwari and Cummins, 2011; Singh et al., 2013). Oat fibers (containing $\beta$-glucan, an indigestible polysaccharide) were proven to increase immunity, to improve anticancer activity and lower blood cholesterol, lipids and blood glucose. Adding oat fibers in yogurt fostered the creation of a good fermented product, with insignificant drop in flavour quality and only a minor decline in texture quality (Khanna and Mohan, 2016).

Chickpea (Cicerarietinum L) is one of the most consumed legumes worldwide. Among their benefits are the high protein concentrations that reflect not only at the nutritional level but also on the supply of active peptides; besides, it represents different metabolites with pharmacological activities (Chang et al., 2009). Some biological activities identified in the different compounds of chickpea are antioxidant, antihypertensive, hypocholesterolemic, and anticancer (Ghribi et al, 2015). Although most reports are based on the effect of proteins and their hydrolysates, alcoholic extracts have also been proven that contain phenolic compounds, saponins, phytates, among others; therefore, their consumption has been dubbed as an alternative for the prevention of chronic degenerative diseases (Faridyet al., 2020).

The aim of this study was to evaluate the effect of the addition of two types of fibers sources (oat and chickpea powders) on the rheological, physicochemical and sensory characteristics of yogurt.

\section{MATERIALS AND METHODS}

\section{Materials}

\section{Milk}

Fresh buffalo's standardized milk (3\% fat) was obtained from Dairy Technology Unit, Food Science Department, Faculty of Agriculture, Zagazig University, Egypt.

\section{Preparation of oat and chickpea powders}

Oat and chickpea were purchased from local market at Zagazig; the seeds were cleaned and rendered free of dust, dirt, foreign materials and broken seed.Ground seeds were converted to the powder form, and sieved with 40, 60 mesh sizes sieves.

\section{Starter cultures}

Streptococcus salivarius subsp. thermophilus EMCC104 and Lactobacillus delbruekii subsp. bulgaricusEMCC1102were obtained from the Microbiological Resources Center (MIRCEN), Faculty of Agric. Aim Shams Univ., Egypt.

\section{Methods}

\section{Manufacture of yogurt}

Fresh bulk buffalo's milk containing 3\% fat was used in the preparation of yogurt and served as a control (C). Buffalo's milk (3\% fat) was divided into 6 equal portions. Oat powder was added to three portions at the rate of 1,2 and 3\% (T1, T2 and T3). Chickpea powder was added to the other three portions at rate of 1,2 and 3\% (T4, T5 and T6). Each milk treatments were homogenized and heated to $90^{\circ} \mathrm{C}$ for $15 \mathrm{~min}$., then, cooled to $42 \pm 1{ }^{\circ} \mathrm{C}$, inoculated with $2 \%$ of yogurt starter cultures, filled in plastic cups and incubated at $42^{\circ} \mathrm{C}$ until a uniform coagulation was obtained. The yogurt samples of all treatments were stored at $5 \pm 2{ }^{\circ} \mathrm{C}$ and analyzed when fresh and after 5,10 and 15 days of storage. All treatments were carried out intriplicates. 


\section{Chemical analysis}

Total solids, fat, ash, crude fiber total protein (TN) contents, titratable acidity and dietary fiber of yogurt samples were determined according to AOAC (2007). The changes in $\mathrm{pH}$ values of yogurt samples during storage were measured using a laboratory $\mathrm{pH}$ meter with glass electrode (HANNA, Instrument, Portugal).

\section{Rheological measurements}

The viscosity and released whey of yogurt samples were measured according to the method of Aryana (2003). The quantity of whey collected from every sample in graduated cylinder after $2 \mathrm{~h}$ of drainage at $20^{\circ} \mathrm{C}$ was used as an index of syneresis. Viscosity of yogurt samples was determined using Rotational Viscometer Type Lab. Line Model 5437.

\section{Sensory evaluation}

The sensory properties of yogurt samples were assessed by 10 panel members of the Dairy Sci., Dep., Fac. Agric., Zagazig, Univ. for flavour (60) body and texture (30) and appearance (10) as reported byNelson and Trout (1981).

\section{Determination of total phenolic content}

Total phenolic content (TPC) of different extracts was measured by using UV spectrophotometer (Jenway-UV-VIS Spectrophotometer), based on a colorimetric oxidation/reduction reaction, as described by Skerget et al. (2005). Total phenolic content expressed as gallic acid equivalent (GAE) was calculated, and the results were expressed as an mg GAE g ${ }^{-1}$ extract (AOAC, 2007).

\section{Determination of total flavonoid content in oat and chickpea}

The total flavonoid content was determined by the aluminum chloride colorimetric method according to Lin and Tang (2007). Quercetin was used as the reference standard and the results were milligram quercetin equivalents (mg EQ)/g.

\section{Radical scavenging activity (Scavenging DPPH)}

The electron donation ability of the obtained extracts was measured by bleaching of the purple colored solution of DPPH according to the method of Hanatoet al. (1988). The absorbance was determined against a control at $517 \mathrm{~nm}$ (Gulcinet al., 2004). Percentage of antioxidant activity of DPPH was calculated as follows:

DPPH scavenging effect $\%=((\mathrm{A} 0-\mathrm{A} 1) / \mathrm{A} 0) \times 100$

Where, $\mathrm{A} 0$ is the absorbance of the control reaction and A1 is the absorbance in the extract. Samples were analyzed in triplicate.

\section{Microbiological analysis}

Microbiological analyses were performedfor freshtreatments and after 5, 10, and 15 days of storage at $5 \pm 2{ }^{\circ} \mathrm{C}$. Total bacterial count (T.B.C) was determined using plate count agar method according to Houghtby et al. (1992). Coliform bacteria and yeast and mould counts were determined according to Marshall (1992). The enumeration of Streptococcus salivarius subsp. thermophilus was performed at $37^{\circ} \mathrm{C}$ for $48 \mathrm{hr}$. under anaerobic condition using M17agar (Oxoid Ltd). Counting of Lactobacillus delbrueckii subsp. bulgaricus was carried out on MRS agar (Oxoid Ltd) the plates were incubated in anaerobic condition at $42^{\circ} \mathrm{C}$ for $48 \mathrm{hr}$. Rybka and Kailasaphaty (1996).

\section{Statistical Analysis}

Data were statistically analyzed using the general linear models procedure of the statistical analysis system SAS (1998). Significances of differences were defined at $\mathrm{p}<0.05$. All experiments were repeated three times and all obtained data are expressed as an average.

\section{RESULTS AND DISCUSSION}

\section{Chemical Composition of Oat and Chickpea Powders}

The proximate chemicalcomposition of oatand chickpea powdersare illustrated in Table 1. The results showed that there is a difference between for each macro nutrients contents. Moisture, protein, fat, ash and fiber contents of oat powder were $(8.14,10.94,7.80,0.09$ and $9.36 \mathrm{~g} / 100 \mathrm{~g}$ respectively. These results are in agreement with the data obtained by Fistes $\boldsymbol{e t} \boldsymbol{a l}$. (2014). Moisture, protein, fat, ash and fiber contents of chickpea powder were $(6.34,26.40$, $6.20,3.14$ and $3.96 \mathrm{~g} / 100 \mathrm{~g}$ ), respectively. These results are in agreement with the data obtained by Wani and Kumar (2014). 
Table 1. Chemical composition, Total phenolic, flavonoid contents and radical scavenging activity of oatand chickpea powders

\begin{tabular}{lcc}
\hline Chemical composition & Oat powder & Chickpea powder \\
\hline Moisture (\%) & $8.14 \pm 0.06^{\mathrm{a}}$ & $6.34 \pm 0.08^{\mathrm{b}}$ \\
Total protein (\%) & $10.94 \pm 0.11^{\mathrm{b}}$ & $26.40 \pm 0.04^{\mathrm{a}}$ \\
Fat (\%) & $7.80 \pm 0.04^{\mathrm{a}}$ & $6.20 \pm 0.06^{\mathrm{b}}$ \\
Ash (\%) & $4.50 \pm 0.12^{\mathrm{a}}$ & $3.14 \pm 0.16^{\mathrm{b}}$ \\
Fiber (\%) & $9.36 \pm 0.06^{\mathrm{a}}$ & $3.96 \pm 0.09^{\mathrm{b}}$ \\
Total phenolic content(mg/100g) & $130.70 \pm 8.60^{\mathrm{b}}$ & $270.40 \pm 12.14^{\mathrm{a}}$ \\
Total flavonoid content (mg/100g) & $72.80 \pm 4.20^{\mathrm{b}}$ & $104.26 \pm 8.32^{\mathrm{a}}$ \\
Radical scavenging activity (\%) & $68.86 \pm 2.22^{\mathrm{b}}$ & $72.50 \pm 2.34^{\mathrm{a}}$ \\
\hline
\end{tabular}

* Values (means \pm SD) with different superscript letters are statistically significantly different $(P \leq 0.05)$.

Table 1 revealed that, the TPC of ethanolic oat and chickpea extracts were 130.70 and $270.40 \mathrm{mg} / 100 \mathrm{~g}$, respectively. While the TFC of ethanolic oat and chickpea extracts were 72.80 and $104.26 \mathrm{mg} / 100 \mathrm{~g}$, respectively. RSA $(\%)$ of ethanolic oat and chickpea extracts were 68.86 and $72.50 \%$, respectively. These results agree with those previously reported by Ibrahim et al. (2020) for oat, Segevet al. (2011) for chickpea.

\section{Chemical Compositionof Different Types of Fortified Yogurt}

Chemical compositions of fortified yogurt samples are shown in Tables 2 and 3. Control yogurt samples had the lowest total solids (TS) and it was significantly $(P \leq 0.05)$ compared with fortified yogurt treatments. The TS content of yogurt containing oatand chickpea powders at different concentrations increased gradually by increasing the percentage added, butchickpea yogurt treatments had the highest TS contents compared with others fortified yogurt treatments. The TS content of all yogurt treatments slightly increased as storage period progressed.

Control yogurt (C) had the lowest protein content. The total protein of yogurt containing oat and chickpea powders at different concentrations increased gradually by increasing the percentage added, chickpea yogurt treatments had the highest protein contents compared with others fortified yogurt treatments. The total protein of all yogurt treatments slightly increased as storage period progressed.

Supplementation of yogurt with oat and chickpea powders at different concentrations slightly increased fat contents by increasing the percentage added, oat yogurt treatments had the highest fat contents compared with others fortified yogurt treatments. The fat of all yogurt treatments slightly increased as storage period progressed.

Supplementation of yogurt with oat and chickpea powders at different concentrations slightly increased ash contents by increasing the percentage added, oat yogurt treatments had the highest fat contents compared with others fortified yogurt treatments. The of all yogurt treatments slightly increased as storage period progressed

Total fiber content of yogurt treatments increased by adding oat and chickpea powders at different concentrations and these increments were proportional to the fortification ratio, oat yogurt treatments had the highest fiber contents compared with others fortified yogurt treatments. The fiber content of all yogurt treatments slightly increased as storage period progressed. These results are in agreement with the data obtained by Karaca et al. (2019) and Pérez-chabelaet al. (2021). 
Table 2. Total solids, fat and protein contents of different fortified yogurt types during storage period

\begin{tabular}{|c|c|c|c|c|c|c|c|c|c|c|c|}
\hline \multirow[t]{3}{*}{ Samples } & \multicolumn{3}{|c|}{ T.S (\%) } & & \multicolumn{3}{|c|}{ Fat $(\%)$} & \multicolumn{4}{|c|}{ Protein (\%) } \\
\hline & \multicolumn{4}{|c|}{ Storage period (days) } & \multicolumn{3}{|c|}{ Storage period (days) } & \multicolumn{4}{|c|}{ Storage period (days) } \\
\hline & fresh & 5 & 10 & fresh & 5 & 10 & 15 & fresh & 5 & 10 & 15 \\
\hline $\mathbf{C}$ & $14.34 \pm 0.04^{\mathrm{f}}$ & $15.12 \pm 0.03^{\mathrm{f}}$ & $16.04 \pm 0.04^{\mathrm{f}}$ & $16.70 \pm 0.21^{\mathrm{f}} \quad 3.1 \pm 0.15^{\mathrm{c}}$ & $3.25 \pm 0.15^{\mathrm{c}}$ & $3.35 \pm 0.15^{\mathrm{c}}$ & $3.40 \pm 0.15^{\mathrm{c}}$ & $3.70 \pm 0.02^{\mathrm{e}}$ & $4.20 \pm 0.02^{\mathrm{e}}$ & $5.00 \pm 0.09^{\mathrm{e}}$ & $5.26 \pm 0.06^{\mathrm{e}}$ \\
\hline T1 & $15.20 \pm 0.02^{\mathrm{e}}$ & $16.03 \pm 0.03^{\mathrm{e}}$ & $16.92 \pm 0.12^{\mathrm{e}}$ & $17.65 \pm 0.14^{\mathrm{e}} 3.20 \pm 0.10^{\mathrm{b}}$ & $3.34 \pm 0.10^{\mathrm{b}}$ & $3.40 \pm 0.10^{\mathrm{b}}$ & $3.48 \pm 0.10^{\mathrm{b}}$ & $3.80 \pm 0.03^{\mathrm{d}}$ & $4.36 \pm 0.02^{\mathrm{d}}$ & $5.14 \pm 0.05^{\mathrm{d}}$ & $5.38 \pm 0.08^{\mathrm{d}}$ \\
\hline $\mathbf{T} 2$ & $16.02 \pm 0.02^{\mathrm{d}}$ & $16.80 \pm 0.03^{\mathrm{d}}$ & $17.72 \pm 0.07^{\mathrm{d}}$ & $18.54 \pm 0.09^{\mathrm{d}} 3.28 \pm 0.10^{\mathrm{ab}}$ & $3.42 \pm 0.10^{\mathrm{ab}}$ & $3.48 \pm 0.10^{\mathrm{ab}}$ & $3.70 \pm 0.10^{\mathrm{ab}}$ & $3.92 \pm 0.02^{\mathrm{d}}$ & $4.48 \pm 0.02^{\mathrm{d}}$ & $5.26 \pm 0.05^{\mathrm{d}}$ & $5.66 \pm 0.06^{\mathrm{d}}$ \\
\hline T4 & $15.30 \pm 0.02^{\mathrm{e}}$ & $16.02 \pm 0.02^{\mathrm{e}}$ & $16.93 \pm 0.07^{\mathrm{e}}$ & $17.60 \pm 0.08^{\mathrm{e}} 3.16 \pm 0.10^{\mathrm{cd}}$ & $3.30 \pm 0.10^{\mathrm{cd}}$ & $3.42 \pm 0.10^{\mathrm{cd}}$ & $3.50 \pm 0.10^{\mathrm{cd}}$ & $4.00 \pm 0.02^{\mathrm{c}}$ & $4.50 \pm 0.02^{\mathrm{c}}$ & $5.24 \pm 0.04^{\mathrm{c}}$ & $5.55 \pm 0.07^{\mathrm{c}}$ \\
\hline T5 & $16.22 \pm 0.02^{\mathrm{c}}$ & $16.92 \pm 0.02^{\mathrm{c}}$ & $17.85 \pm 0.06^{\mathrm{c}}$ & $18.54 \pm 0.06^{\mathrm{c}} 3.22 \pm 0.10^{\mathrm{b}}$ & $3.36 \pm 0.10^{\mathrm{b}}$ & $3.48 \pm 0.10^{\mathrm{b}}$ & $3.55 \pm 0.10^{\mathrm{b}}$ & $4.26 \pm 0.02^{\mathrm{b}}$ & $4.78 \pm 0.03^{b}$ & $5.50 \pm 0.57^{\mathrm{b}}$ & $5.82 \pm 0.08^{b}$ \\
\hline T6 & $17.14 \pm 0.02^{\mathrm{a}}$ & $17.83 \pm 0.02^{\mathrm{a}}$ & $18.70 \pm 0.04^{\mathrm{a}}$ & $19.35 \pm 0.10^{\mathrm{a}} 3.30 \pm 0.10^{\mathrm{ab}}$ & $3.42 \pm 0.15^{\mathrm{ab}}$ & $3.56 \pm 0.15^{\mathrm{ab}}$ & $3.62 \pm 0.21^{\mathrm{ab}}$ & $4.50 \pm 0.02^{\mathrm{a}}$ & $5.03 \pm 0.03^{\mathrm{a}}$ & $5.79 \pm 0.50^{\mathrm{a}}$ & $6.08 \pm 0.08^{\mathrm{a}}$ \\
\hline
\end{tabular}

Table 3. Ash and fiber contents of different fortified yogurt types during storage period

\begin{tabular}{|c|c|c|c|c|c|c|c|c|}
\hline \multirow[t]{3}{*}{ Samples } & \multicolumn{4}{|c|}{$\operatorname{Ash}(\%)$} & \multicolumn{4}{|c|}{ Fiber \% } \\
\hline & \multicolumn{4}{|c|}{ Storage period (days) } & \multicolumn{4}{|c|}{ Storage period (days) } \\
\hline & fresh & 5 & 10 & 15 & fresh & 5 & 10 & 15 \\
\hline $\mathbf{C}$ & $0.74 \pm 0.02^{\mathrm{d}}$ & $0.78 \pm 0.04^{\mathrm{d}}$ & $0.82 \pm 0.04^{\mathrm{d}}$ & $0.90 \pm 0.05^{\mathrm{d}}$ & $0.00 \pm 0.02^{\mathrm{d}}$ & $0.00 \pm 0.002^{\mathrm{d}}$ & $0.00 \pm 0.002^{\mathrm{d}}$ & $0.00 \pm 0.002^{\mathrm{d}}$ \\
\hline T1 & $0.80 \pm 0.02^{\mathrm{c}}$ & $0.82 \pm 0.02^{\mathrm{c}}$ & $0.87 \pm 0.05^{\mathrm{c}}$ & $0.95 \pm 0.06^{\mathrm{c}}$ & $0.09 \pm 0.02^{\mathrm{bc}}$ & $0.14 \pm 0.01^{\mathrm{bc}}$ & $0.20 \pm 0.02^{\mathrm{bc}}$ & $0.32 \pm 0.02^{\mathrm{bc}}$ \\
\hline $\mathbf{T} 2$ & $0.85 \pm 0.02^{\mathrm{b}}$ & $0.86 \pm 0.03^{b}$ & $0.93 \pm 0.06^{\mathrm{b}}$ & $1.00 \pm 0.06^{\mathrm{b}}$ & $0.20 \pm 0.02^{\mathrm{a}}$ & $0.26 \pm 0.01^{\mathrm{a}}$ & $0.34 \pm 0.01^{\mathrm{a}}$ & $0.40 \pm 0.02^{\mathrm{a}}$ \\
\hline T3 & $0.90 \pm 0.02^{\mathrm{a}}$ & $0.90 \pm 0.03^{\mathrm{a}}$ & $0.98 \pm 0.05^{\mathrm{a}}$ & $1.06 \pm 0.06^{\mathrm{a}}$ & $0.28 \pm 0.01^{\mathrm{b}}$ & $0.35 \pm 0.01^{\mathrm{b}}$ & $0.42 \pm 0.02^{\mathrm{b}}$ & $0.50 \pm 0.01^{\mathrm{b}}$ \\
\hline $\mathbf{T 4}$ & $0.78 \pm 0.01^{\mathrm{c}}$ & $0.81 \pm 0.05^{\mathrm{c}}$ & $0.85 \pm 0.05^{\mathrm{c}}$ & $0.94 \pm 0.04^{\mathrm{c}}$ & $0.03 \pm 0.02^{\mathrm{c}}$ & $0.09 \pm 0.02^{\mathrm{c}}$ & $0.15 \pm 0.02^{\mathrm{c}}$ & $0.22 \pm 0.02^{\mathrm{c}}$ \\
\hline T5 & $0.82 \pm 0.02^{\mathrm{c}}$ & $0.84 \pm 0.04^{\mathrm{c}}$ & $0.88 \pm 0.04^{\mathrm{c}}$ & $0.98 \pm 0.07^{\mathrm{c}}$ & $0.08 \pm 0.01^{\mathrm{bc}}$ & $0.14 \pm 0.01^{\mathrm{bc}}$ & $0.22 \pm 0.02^{\mathrm{bc}}$ & $0.30 \pm 0.02^{\mathrm{bc}}$ \\
\hline T6 & $0.85 \pm 0.02^{\mathrm{b}}$ & $0.87 \pm 0.04^{\mathrm{b}}$ & $0.92 \pm 0.06^{\mathrm{b}}$ & $1.02 \pm 0.05^{\mathrm{b}}$ & $0.12 \pm 0.02^{\mathrm{b}}$ & $0.20 \pm 0.01^{\mathrm{b}}$ & $0.29 \pm 0.01^{\mathrm{b}}$ & $0.36 \pm 0.01^{\mathrm{b}}$ \\
\hline
\end{tabular}

* Values (means \pm SD) with different superscript letters are statistically significantly different $(P \leq 0.05)$.

C: Control yogurt (3\% fat). , T1 : yogurt with $1 \%$ oat powder ,T2: : yogurt with $2 \%$ oat powder ,T3: yogurt with $3 \%$ oat powder,T4: yogurt with $1 \%$ chickpea powder ,T5: yogurt with $2 \%$ chickpea powder,T6: yogurt with $3 \%$ chickpea powder. 


\section{pH and Titratableacidity Values of Different Types of Fortified Yogurt}

Table 4 shows the effect of adding oatand chickpea powders at different concentrations on $\mathrm{pH}$ and titratable acidity of resultant yogurt. Addition of oat and chickpea powders at different concentrations increased the $\mathrm{pH}$ values in yogurt. Whereas, titratable acidity decreased with increasing fortification ratio. Acidity of all yogurt treatments increased as storage period progressed, while $\mathrm{pH}$ of all yogurt treatments decreased as storage period progressed .Similar observation was reported by Atwaaet al, (2020) and Pérez-chabelaet al. (2021).

\section{Rheological Properties}

Fortification of yogurt with oat and chickpea powders at different concentrations significantly decreased whey syneresis and increasedviscosity compared with control yogurt and this increasing was proportional to the fortification ratio (Table 5). These results might be due to increasing the water holding capacity ofoat and chickpea powders. Viscosity of all yogurt treatments increased as storage period progressed up to 10 days and then decreased up to the end of storage period. While whey syneresis of all yogurt treatments decreased as storage period progressed up to 10 days and then increased at the end of storage period. These results are in agreement with those reported by Karacaet al. (2019) and Pérez-chabelaet al. (2021).

\section{Total Phenolic Content (TFCmg/100 g) and Radical Scavenging Activity (RSA) of Different Types of Fortified Yogurt}

Phenolic contents and antioxidant activity of yogurt samples are presented in Table 6 There were significant differences in the phenolic contents and antioxidant activity of the samples $(\mathrm{P}<0.05)$. Addition ofoat and chickpea powders at different concentrations significantly increased phenolic contents and antioxidant activity of yogurt treatmentsand these increments were proportional to the fortification ratio. The highest value of phenolic contents and antioxidant activity at the end of storage period was for yogurt fortified with 3\% oat powders. Similar observation was reported by Atwaaet al. (2020) and Pérez-chabelaet al. (2021). Phenolic contents and antioxidant activity of all yogurt treatments decreased as storage period progressed.

\section{Microbiological Evaluation of Different Types of Fortified Yogurt}

Table 7 shows the differences in total bacterial counts of plain and fortified yogurt during storage period. The results indicated that total bacterial count decreased gradually as storage period progressed until the end of storage period. Yogurt treatments fortified with oat and chickpea powders at different concentrations had the lowest counts of total bacterial count. Total bacterial count decreased with increasing the fortification ratio.

Yeast and mould counts increased in all treatments up to the end of storage period yogurt treatments fortified with oat and chickpea powders at different concentrations had the lowest yeast and moulds counts. Yeast and moulds counts decreased with increasing the fortification ratio.

Coliform bacteria not detected in all treatments up to the end of storage period. These results may be due to high antibacterial or antifungal properties of oat and chickpea powders (Arena et al, 2016; Kanet al, 2010).

Streptococcus salivarius subsp. thermophilus and Lactobacillus delbruekii subsp. bulgaricuscounts increased gradually in all treatments up to 5 days form storage and then decreased at the end of storage period. Yogurt treatments fortified with oat and chickpea powders at different concentrations had the lowest Streptococcus salivarius subsp. thermophilus and Lactobacillus delbruekii subsp. bulgaricus counts (Table 8). Fortification of yogurt with oat and chickpea powders decreased the countsof Streptococcus salivarius subsp. thermophilus and Lactobacillus delbruekii subsp. bulgaricuscompared to control yogurt and this may be due to high antibacterial or antifungal properties of oat and chickpea. The general trend of these results agreed with those reported Elsanhoty and Ramadan (2018) and Habibet al. (2018).

\section{Sensory Evaluations of Different Types of Fortified Yogurt}

Results in Table 9 showed that there was different between control and fortified yogurt for sensory attributes; control yogurt had the lowest values. Addition of oat and chickpea 
Table 4. $\mathrm{pH}$ and acidity values of different fortified yogurt types during storage period

\begin{tabular}{|c|c|c|c|c|c|c|c|c|}
\hline \multirow[t]{3}{*}{$\overline{\text { Samples }}$} & \multicolumn{4}{|c|}{ Titratable (lactic acid \%) } & \multicolumn{4}{|c|}{ pH } \\
\hline & \multicolumn{4}{|c|}{ Storage period (days) } & \multicolumn{4}{|c|}{ Storage period (days) } \\
\hline & fresh & 5 & 10 & 15 & fresh & 5 & 10 & 15 \\
\hline $\mathbf{C}$ & $0.88 \pm 0.03^{\mathrm{b}}$ & $0.95 \pm 0.03^{\mathrm{b}}$ & $1.02 \pm 0.02^{\mathrm{b}}$ & $1.12 \pm 0.03^{\mathrm{b}}$ & $4.30 \pm 0.03^{\mathrm{bc}}$ & $4.16 \pm 0.02^{\mathrm{bc}}$ & $4.05 \pm 0.03^{\mathrm{bc}}$ & $3.95 \pm 0.02^{\mathrm{bc}}$ \\
\hline T1 & $0.92 \pm 0.04^{\mathrm{a}}$ & $1.00 \pm 0.03^{\mathrm{a}}$ & $1.07 \pm 0.03^{\mathrm{a}}$ & $1.22 \pm 0.03^{\mathrm{a}}$ & $4.28 \pm 0.03^{\mathrm{c}}$ & $4.14 \pm 0.02^{\mathrm{c}}$ & $4.02 \pm 0.02^{\mathrm{c}}$ & $4.00 \pm 0.02^{\mathrm{c}}$ \\
\hline $\mathbf{T} 2$ & $0.88 \pm 0.04^{\mathrm{b}}$ & $0.92 \pm 0.03^{\mathrm{b}}$ & $0.98 \pm 0.03^{\mathrm{b}}$ & $1.06 \pm 0.03^{\mathrm{b}}$ & $4.36 \pm 0.04^{\mathrm{b}}$ & $4.25 \pm 0.31^{\mathrm{b}}$ & $4.18 \pm 0.02^{\mathrm{b}}$ & $4.09 \pm 0.02^{\mathrm{b}}$ \\
\hline $\mathbf{T 3}$ & $0.86 \pm 0.03^{\mathrm{bc}}$ & $0.90 \pm 0.02^{\mathrm{bc}}$ & $0.94 \pm 0.03^{\mathrm{bc}}$ & $1.02 \pm 0.03^{\mathrm{bc}}$ & $4.40 \pm 0.07^{\mathrm{ab}}$ & $4.31 \pm 0.03^{\mathrm{ab}}$ & $4.22 \pm 0.02^{\mathrm{ab}}$ & $4.15 \pm 0.02^{\mathrm{ab}}$ \\
\hline T4 & $0.90 \pm 0.03^{\mathrm{ab}}$ & $0.98 \pm 0.02^{\mathrm{ab}}$ & $1.04 \pm 0.03^{\mathrm{ab}}$ & $1.16 \pm 0.03^{\mathrm{ab}}$ & $4.30 \pm 0.03^{\mathrm{bc}}$ & $4.12 \pm 0.02^{\mathrm{bc}}$ & $4.00 \pm 0.02^{\mathrm{bc}}$ & $3.92 \pm 0.02^{\mathrm{bc}}$ \\
\hline T5 & $0.86 \pm 0.04^{\mathrm{bc}}$ & $0.90 \pm 0.03^{\mathrm{bc}}$ & $0.95 \pm 0.03^{\mathrm{bc}}$ & $1.02 \pm 0.02^{\mathrm{bc}}$ & $4.38 \pm 0.04^{\mathrm{ab}}$ & $4.28 \pm 0.02^{\mathrm{ab}}$ & $4.22 \pm 0.02^{\mathrm{ab}}$ & $4.14 \pm 0.02^{\mathrm{ab}}$ \\
\hline T6 & $0.86 \pm 0.03^{\mathrm{bc}}$ & $0.89 \pm 0.02^{\mathrm{bc}}$ & $0.92 \pm 0.03^{b c}$ & $0.98 \pm 0.03^{\mathrm{bc}}$ & $4.44 \pm 0.04^{\mathrm{a}}$ & $4.35 \pm 0.02^{\mathrm{a}}$ & $4.26 \pm 0.02^{\mathrm{a}}$ & $4.22 \pm 0.02^{\mathrm{a}}$ \\
\hline
\end{tabular}

* Values (means $\pm \mathrm{SD}$ ) with different superscript letters are statistically significantly different $(P \leq 0.05)$.

C: Control yogurt (3\% fat). , T1 : yogurt with $1 \%$ oat powder ,T2: : yogurt with $2 \%$ oat powder ,T3: yogurt with 3\% oat powder,T4: yogurt with 1\% chickpea powder ,T5: yogurt with $2 \%$ chickpea powder,T6: yogurt with $3 \%$ chickpea powder .

Table 5. Viscosity and Synersses of different fortified yogurt types during storage period

\begin{tabular}{|c|c|c|c|c|c|c|c|c|}
\hline \multirow[t]{3}{*}{$\overline{\text { Samples }}$} & \multicolumn{4}{|c|}{ Viscosity (mPa) } & \multicolumn{4}{|c|}{ Syneresses $(\mathrm{ml} / \mathbf{1 0 0 m l})$} \\
\hline & \multicolumn{4}{|c|}{ Storage period (days) } & \multicolumn{4}{|c|}{ Storage period (days) } \\
\hline & fresh & 5 & 10 & $\overline{15}$ & fresh & 5 & 10 & $\overline{15}$ \\
\hline $\bar{C}$ & $5200 \pm 25.17^{\mathrm{e}}$ & $5600 \pm 30.00^{\mathrm{e}}$ & $6000 \pm 20^{\mathrm{e}}$ & $5900 \pm 26.44^{\mathrm{e}}$ & $28.67 \pm 1.53^{\mathrm{a}}$ & $25.00 \pm 2.00^{\mathrm{a}}$ & $22.33 \pm 1.53^{\mathrm{a}}$ & $24.00 \pm 2.00^{\mathrm{a}}$ \\
\hline T1 & $5280 \pm 30.55^{\mathrm{e}}$ & $5760 \pm 20.00^{\mathrm{e}}$ & $6140 \pm 20.28^{\mathrm{e}}$ & $5970 \pm 597.75^{\mathrm{e}}$ & $27.0 \pm 1.53^{\mathrm{b}}$ & $24.0 \pm 1.15^{\mathrm{b}}$ & $20.00 \pm 2.00^{\mathrm{b}}$ & $22.00 \pm 2.00^{\mathrm{c}}$ \\
\hline $\mathbf{T} 2$ & $5350 \pm 35.12^{\mathrm{c}}$ & $5820 \pm 20.00^{c}$ & $6250 \pm 20.00^{c}$ & $6070 \pm 20.00^{c}$ & $26.00 \pm 2.00^{\mathrm{bc}}$ & $23.00 \pm 2.00^{\mathrm{bc}}$ & $18.00 \pm 2.00^{\mathrm{bc}}$ & $22.00 \pm 2.00^{\mathrm{c}}$ \\
\hline T3 & $5500 \pm 20.00^{\mathrm{a}}$ & $5900 \pm 106.93^{\mathrm{a}}$ & $6350 \pm 20.82^{\mathrm{a}}$ & $6180 \pm 26.46^{\mathrm{a}}$ & $25.00 \pm 2.00^{\mathrm{c}}$ & $23.00 \pm 2.00^{\mathrm{c}}$ & $17.00 \pm 2.00^{\mathrm{c}}$ & $20.00 \pm 2.00^{\mathrm{d}}$ \\
\hline T4 & $5220 \pm 35.12^{\mathrm{e}}$ & $5730 \pm 268.51^{\mathrm{e}}$ & $5900 \pm 20.00^{\mathrm{e}}$ & $5840 \pm 30.55^{\mathrm{e}}$ & $28.00 \pm 2.52^{\mathrm{a}}$ & $25.00 \pm 2.00^{\mathrm{a}}$ & $21.00 \pm 2.00^{\mathrm{a}}$ & $24.00 \pm 2.00^{\mathrm{a}}$ \\
\hline T5 & $5280 \pm 30.00^{\mathrm{d}}$ & $5790 \pm 30.00^{\mathrm{d}}$ & $6180 \pm 20.82^{\mathrm{d}}$ & $6000 \pm 20.82^{\mathrm{d}}$ & $28.00 \pm 1.53^{\mathrm{a}}$ & $24.00 \pm 2.00^{\mathrm{b}}$ & $20.00 \pm 2.00^{\mathrm{b}}$ & $23.00 \pm 2.00^{\mathrm{bc}}$ \\
\hline T6 & $5420 \pm 595.01^{\mathrm{b}}$ & $5840 \pm 30.00^{\mathrm{b}}$ & $6210 \pm 20.00^{\mathrm{b}}$ & $6140 \pm 20.82^{\mathrm{b}}$ & $26.00 \pm 2.08^{\text {bc }}$ & $24.00 \pm 2.00^{\mathrm{b}}$ & $20.00 \pm 2.00^{\mathrm{b}}$ & $23.00 \pm 2.00^{\mathrm{bc}}$ \\
\hline
\end{tabular}

* Values (means + SD) with different superscript letters are statistically significantly different $(P \leq 0.05)$.

C: Control yogurt (3\% fat)., T1 : yogurt with $1 \%$ oat powder, T2: : yogurt with $2 \%$ oat powder ,T3: yogurt with $3 \%$ oat powder,T4: yogurt with $1 \%$ chickpea powder ,T5: yogurt with $2 \%$ chickpea powder,T6: yogurt with $3 \%$ chickpea powder . 
Table 6. Total phenolic content and radical scavenging activity of different fortified yogurt types during storage period

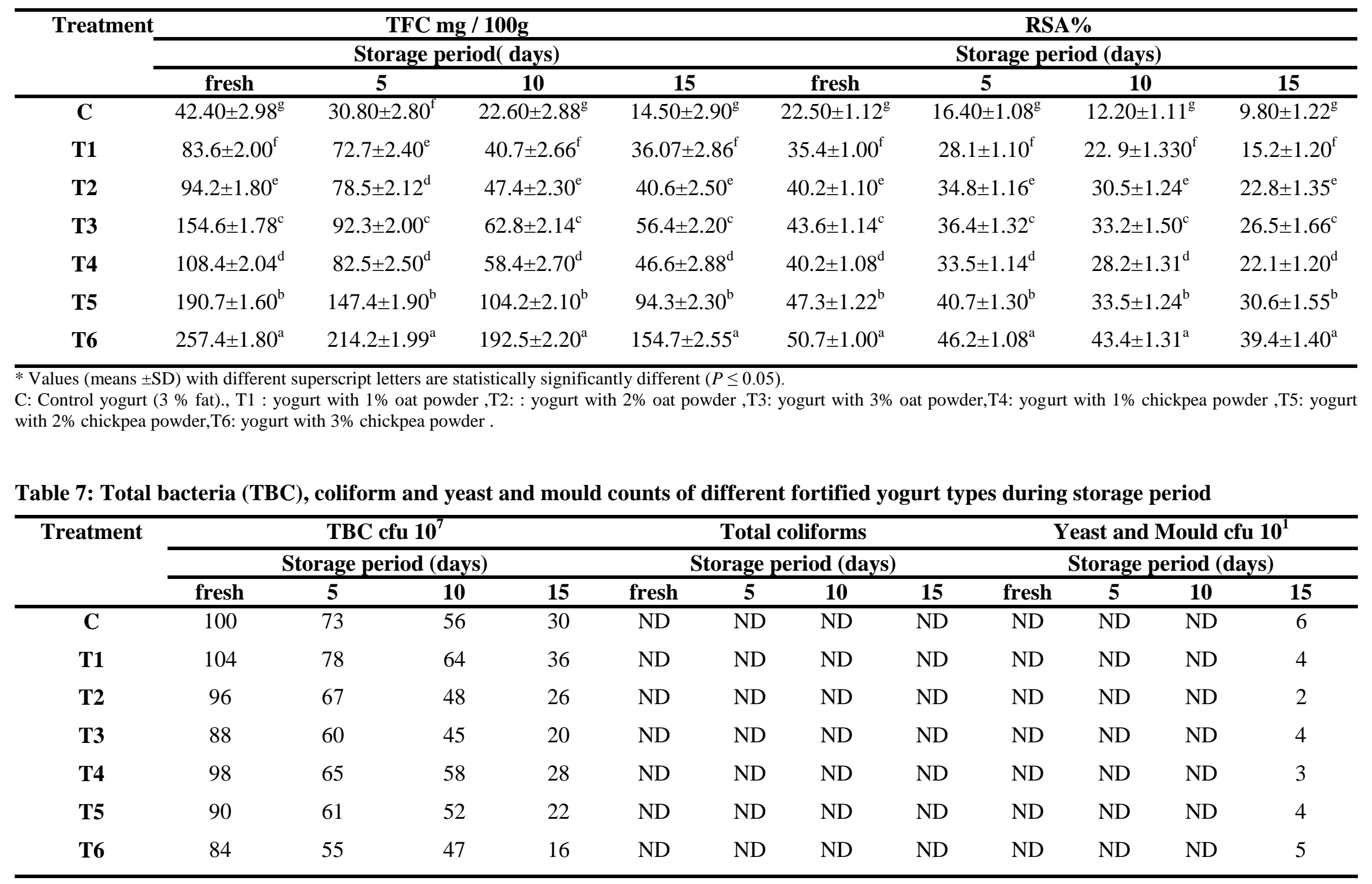

Table 7: Total bacteria (TBC), coliform and yeast and mould counts of different fortified yogurt types during storage period 
Table 8. Streptococcus salivarius subsp. thermophilus and Lactobacillus delbruekii subsp. Bulgaricus counts of different fortified yogurt types during storage period

\begin{tabular}{|c|c|c|c|c|c|c|c|c|}
\hline \multirow[t]{3}{*}{ Treatment } & \multicolumn{4}{|c|}{ Streptococcus salivarius subsp. thermophilus cfu $10^{7}$} & \multicolumn{4}{|c|}{ Lactobacillus delbruekii subsp. bulgaricuscfu $10^{7}$} \\
\hline & \multicolumn{4}{|c|}{\begin{tabular}{|l} 
Storage period (days) \\
\end{tabular}} & \multicolumn{4}{|c|}{$\begin{array}{c}\text { Storage period (days) } \\
\end{array}$} \\
\hline & fresh & 5 & 10 & 15 & fresh & 5 & 10 & 15 \\
\hline $\mathbf{C}$ & 52 & 70 & 68 & 59 & 26 & 44 & 63 & 82 \\
\hline T1 & 56 & 74 & 65 & 47 & 28 & 45 & 72 & 85 \\
\hline $\mathbf{T 2}$ & 43 & 67 & 62 & 39 & 23 & 37 & 66 & 75 \\
\hline $\mathbf{T 3}$ & 34 & 56 & 53 & 28 & 17 & 29 & 53 & 63 \\
\hline T4 & 45 & 66 & 60 & 34 & 25 & 43 & 55 & 61 \\
\hline T5 & 33 & 58 & 50 & 25 & 19 & 31 & 47 & 56 \\
\hline T6 & 29 & 42 & 36 & 22 & 14 & 25 & 38 & 45 \\
\hline
\end{tabular}

C: Control yogurt (3\% fat)., T1 : yogurt with $1 \%$ oat powder ,T2: : yogurt with $2 \%$ oat powder ,T3: yogurt with 3\% oat powder,T4: yogurt with 1\% chickpea powder ,T5: yogurt with $2 \%$ chickpea powder,T6: yogurt with $3 \%$ chickpea powder.

Table 9: Sensory evaluations of different fortified yogurt types during storage period

\begin{tabular}{|c|c|c|c|c|c|c|c|c|c|c|c|c|c|c|c|c|}
\hline \multirow[t]{3}{*}{ Samples } & \multicolumn{4}{|c|}{ Appearance (10) } & \multicolumn{4}{|c|}{ Body and Texture (30) } & \multicolumn{4}{|c|}{ Flavour (60) } & \multicolumn{4}{|c|}{ Total(100) } \\
\hline & \multicolumn{4}{|c|}{ Storage period (days) } & \multicolumn{4}{|c|}{ Storage period (days) } & \multicolumn{4}{|c|}{ Storage period (days) } & \multicolumn{4}{|c|}{ Storage period (days) } \\
\hline & $\overline{\text { fresh }}$ & 5 & 10 & 15 & fresh & 5 & 10 & 15 & fresh & 5 & 10 & 15 & fresh & 5 & 10 & 15 \\
\hline $\mathbf{C}$ & 8 & 8 & 7 & 7 & 28 & 28 & 27 & 26 & 56 & 55 & 55 & 54 & $92 \pm 0.30 \mathrm{~g}$ & $91 \pm 0.32 \mathrm{~g}$ & $89 \pm 0.36 \mathrm{~g}$ & $85 \pm 0.42 \mathrm{~g}$ \\
\hline T1 & 8 & 7 & 7 & 7 & 28 & 28 & 27 & 26 & 58 & 57 & 56 & 55 & $94 \pm 0.22 \mathrm{e}$ & $91 \pm 0.30 \mathrm{e}$ & $89 \pm 3.02 \mathrm{e}$ & $86 \pm 0.34 \mathrm{e}$ \\
\hline $\mathbf{T} 2$ & 9 & 9 & 8 & 8 & 29 & 29 & 28 & 27 & 58 & 58 & 57 & 56 & $96 \pm 0.25 \mathrm{c}$ & $96 \pm 0.33 \mathrm{c}$ & $93 \pm 0.30 \mathrm{c}$ & $90 \pm 0.33 c$ \\
\hline T3 & 9 & 9 & 8 & 8 & 30 & 30 & 29 & 28 & 59 & 59 & 58 & 57 & $98 \pm 0.23 \mathrm{a}$ & $98 \pm 0.30 \mathrm{a}$ & $95 \pm 0.33 \mathrm{a}$ & $92 \pm 0.32 \mathrm{a}$ \\
\hline T4 & 8 & 7 & 7 & 7 & 28 & 28 & 27 & 26 & 57 & 56 & 55 & 54 & $93 \pm 0.20 \mathrm{f}$ & $90 \pm 0.32 \mathrm{f}$ & $88 \pm 0.36 \mathrm{f}$ & $85 \pm 0.35 \mathrm{f}$ \\
\hline T5 & 9 & 9 & 8 & 8 & 29 & 29 & 28 & 27 & 57 & 57 & 56 & 55 & $95 \pm 0.22 \mathrm{~d}$ & $95 \pm 0.36 d$ & $92 \pm 0.34 d$ & $89 \pm 0.33 \mathrm{~d}$ \\
\hline T6 & 9 & 9 & 8 & 8 & 30 & 30 & 29 & 28 & 58 & 58 & 57 & 57 & $97 \pm 0.24 \mathrm{~b}$ & $97 \pm 0.28 \mathrm{~b}$ & $94 \pm 0.30 \mathrm{~b}$ & $91 \pm 0.32 \mathrm{~b}$ \\
\hline
\end{tabular}


powder improved the organoleptic properties of fortified yogurt. The highest mean value was related to sample containing 3\% oat powder .The organoleptic properties of all yogurt treatments decreased as storage period progressed. A similar observation was found by Al-Hamdani et al. (2015) and Atwaa et al. (2020).

\section{REFERENCES}

AOAC (2007). Association of Official Analytical Chemists- Official Method of Analysis $\left(18^{\text {th }}\right.$ Ed.), Benjamin Franklin Station Washington, DC, USA.

Al-Hamdani, M.S., E.H. Al-Anbary and M. Ahmed (2015). Effect of Lupin (Lupinusalbifrons) flour on microbial and sensory properties of local Yoghurt. Advances in Life Sci. and Technol., 34.1-6.

Arena, M.P., P. Russo, V. Capozzi, A. Rascón, G.E. Felis, G. Spano and D. Fiocco (2013). Combinations of cereal $\beta$-glucans and probiotics can enhance the anti- inflammatory activity on host cells by a synergistic effect. J. Funct. Foods, 459 23: 12-23.

Aryana, K.J. (2003). Folic acid fortified fat free plain set yoghurts. Int. J. Dairy Technol., 56 (4): 219-222.

Atwaa, E.H., E.T. AbouSayed-Ahmed and M.A.A. Hassan (2020). Physicochemical, microbiological and sensory properties of low fat probiotic yoghurt fortified with mango pulp fiber waste as source of dietary fiber. J. Food and Dairy Sci., 11 (9): 271276.

Balthazar, C.F., C.A.C. Júnior, J. Moraes, M.P. Costa, R.S.L. Raices, R.M. Franco and A.C.O. Silva (2016). Physicochemical evaluation of sheep milk yogurts containing different levels of inulin. J. Dairy Sci., 99: 4160-4168.

Chang, Y.W., I. Alli, A.T. Molina, Y. Konishi and J.I. Boye (2009). Isolation and characterization of chickpea (Cicerarietinum L.) seed protein fractions. Food Bioproc. Tech., 5:618-625.

Dello Staffolo, M., A. Sato and R. Cunha (2017). Utilization of plant dietary fibers to reinforce low-calorie dairy dessert structure.
Food and Bioprocess Technol., 10(5): 914925.

Dönmez, Ö., B.A. Mogol and V. Gökmen (2017). Syneresis and rheological behaviors of set yogurt containing green tea and green coffee powders. J. Dairy Sci., 100: 901-907.

Elsanhoty, R.M. and M.F. Ramadan (2018). Changes in the physicochemical and microbiological properties of probioticfermented low-fat yoghurt enriched with barley $\beta$-glucan during cold storage. Mljekarstvo, 68 (4): 295-309.

EFSA (2010). European Food Safety Authority. Scientific opinion of the substantiation of health claims related to wheat bran fibre and increase in faecal bulk (ID 3066), reduction in intestinal transit time (ID 828, 839, 3067, 4699) and contribution to the maintenance of achievement of a normal body weight (ID 829 ) pursuant to article 13 (1) of regulation (EC) no. 1924/2006. EFSA J., 8(10): 1817.

Faridy, G.C.M., C.G.M. Stephanie, M.M.O. Gabriela and Cristian G.M.C. (2020). Biological activities of chickpea (Cicer arietinum L.) in human health. A Rev. Plant Foods for Human Nutr., 75: 142-153.

Fistes, A., T. Dosenovi, D’. Raki, B. Pajin, Z². Sere, S. Simovi' and I'. Loncarevi (2014). Statistical analysis of the basic chemical composition of whole grain flour of different cereal grains. Acta. Univ. Sapientiae, Alimentaria, 7 : 45-53.

Ghribi, A.M., A. Sila and R. Przybylski (2015). Purification and identification of novel antioxidant peptides from enzymatic hydrolysate of chickpea (Cicerarietunum L.) protein concentrate. J. Funct. Foods, 12 : $512-525$.

Gulcin, I., O.I. Kufrevioglu, M. Oktay and M.E. Buyukokuroglu (2004). Antioxidant, antimicrobial, antiulcer and analgesic activities of nettle (Urticadioica L.). J. Ethnopharmacol., 90: 205-215.

Habib, E.E., S.M. Shamsia, S.A. Awad and H.M. Ziena (2018). Physicochemical and sensory properties of labneh fortified with Salvia Officinalis. Alex. Sci. Exch. J., 38: 4 761-769. 
Hanato, T., H.Kagawa, T. Yasuhara, and Okuda,T. (1988). Two new flavonoids and other constituents in licorice root: their relative astringency and radical scavenging effects. Chem. Pharm. Bull., 36: 2090-2097.

Houghtby, G.A., L.J. Matuin, E.K. (1992). Microbiological count methods. In: Standard methods for the examination of dairy products Marshall, T.R. (Editor) Ame. Public Health Assoc., Washington, DC., USA.

Ibrahim, M.S., A. Ahmad, A. Sohail and M. Asad (2020). Nutritional and functional characterization of different oat (Avena sativa L.) cultivars. Int. J. Food Prop., 23 (1): 1373-1385.

Kan, A., B. Özçelik and M. Kartal (2010). In vitro antimicrobial activities of Cicerarietinum L. (chickpea). Trop. J. Pharm., 9:475-481.

Karaca, O.B., I.B. Saydam and M. Güven (2019). Physical, chemical, and sensory attributes of low-fat, full-fat, and fat-free probiotic set yogurts fortified with fiber-rich persimmon and apple powders. J. Food Proc. and Preservation, $43: 1$.

Khanna, M.S. (2016). Oats: Understanding the science. Int. J. Food Sci. and Nutr., 1 (6): 110.

Lin, J. and C. Tang (2007). Determination of total phenolic and flavonoid contents in selected fruits and vegetables, as well as their stimulatory effects on mouse splenocyte proliferation. Food Chem., 101: 140-147.

Luana, N., C. Rossana, J.A. Curiel, P. Kaisa, G. Marco and C.G. Rizzello (2014). Manufacture and characterization of a yogurt-like beverage made with oat flakes fermented by selected lactic acid bacteria. Int. J. Food Microbiol., 185: 17-26.

Marshall, R.T. (1992). Standard Methods for the Examination of Dairy Products.16th edit. Ame. Public Health Assoc. (APHA), Washington, D.C. USA, 158.

Nelson, J.A. and G.H. Trout (1981). Judging of dairy products, $4^{\text {th }}$ Ed. INC Westport, Academic Press, 345-567.

Pérez-Chabela, M.L., A. Cebollón-Juárez, E. Bosquez-Molina and A. Totosaus (2021).
Mango peel flour and potato peel flour as bioactive ingredients in the formulation of functional yogurt. Food Sci. Technol., 1-8.

Raju, N.P. and D. Pal (2014). Effect of dietary fibers on physico-chemical, sensory and textural properties of MistiDahi. J. Food Sci. and Technol., 51 (11): 3124-3133.

Rybka and Kailasaphaty (1996). Media for enumeration of yoghurt bacteria. Int. Dairy J., 6: 839 .

SAS (1998). User's guide.6.12 end statistical Analysis System Institute Inc. Cary NC 27511-8000, USA.

Segev, A., H. Badani, Y. Kapulnik, I. Shomer, M. Oren-Shamir and S. Galili (2011). Determination of Polyphenols, Flavonoids, and Antioxidant Capacity in Colored Chickpea (Cicerarietinum L.). J. Food Sci., 75 (2): 115-119.

Shi, J., Y.-P. Han and X.-H. Zhao (2017). Quality attributes of set-style skimmed yoghurt affected by the addition of a crosslinked bovine gelatin. CyTA- J. Food, 15 (2): 320-325.

Singh, R., S. De and A. Belkheir (2013). Avena Sativa. (Oat), a potential neutraceutical and therapeutic agent: an overview. Critical Rev. in Food Sci. and Nutr., 53: 26-144.

Škerget, M., P. Kotnik, M. Hadolin, A. RižnerHraš, M. Simonič and Z. Knez (2005). Phenols, proanthocyanidins, flavones and flavonols in some plant materials and their antioxidant activities. Food Chem., 89: 191198.

Tejada-Ortigoza, V., L.E. Garcia-Amezquita, S. Serna-Saldivari and J. Welti- Chanes (2016). Advances in the functional characterization and extraction processes of dietary fibre. Food Eng. Rev., 8 (3): 251-271.

Tiwari, U. and E. Cummins (2011). Metaanalysis of the effect of beta-glucan intake on blood cholesterol andglucose levels. Nutr., 27 (10): 1008-1016.

Tomic, N., B. Dojnov, J. Miocinovic, I. Tomasevic, N. Smigic, I. Djekic and Z. Vujcic (2017). Enrichment of yoghurt with insoluble dietary fiber from triticale.A 
sensory perspective. LWT- Food Sci. and Technol., 80: 59-66.

Wani, S.A. and P. Kumar (2014). Comparative study of chickpea and green pea flour based on chemical composition, functional and pasting properties. J. Food Res. and Technol., 2 (3): 124-129.
Zhi, N.N., K. Zong, K. Thakur, J. Qu, J.J. Shi, J.L. Yang and Z.J. Wei (2018). Development of a dynamic prediction model for shelf-life evaluation of yogurt by using physicochemical, microbiological and sensory parameters. CYTA- J. Food, 16 (1): $42-49$.

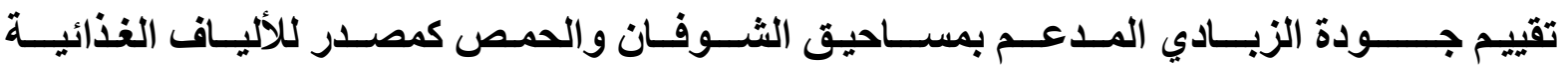

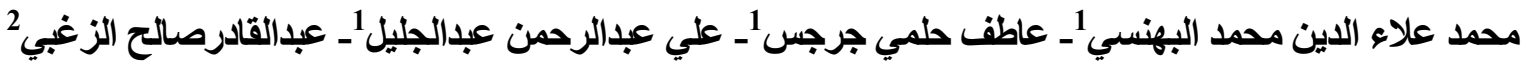

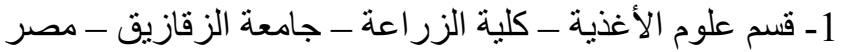

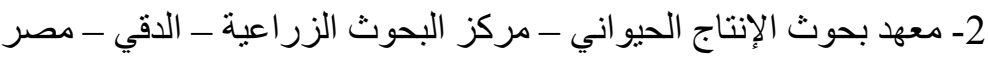

الهدف من هذه الدراسة هو تقييم تأثير إضافة كل من مسحوق الثوفان والحمص على الخصائص الريولئوبية

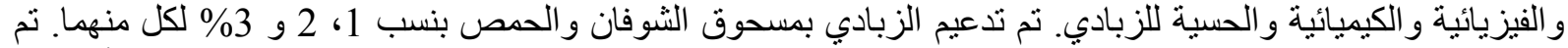

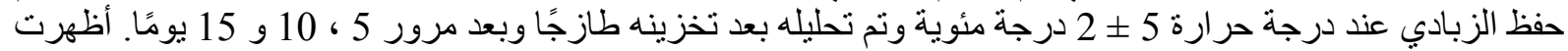

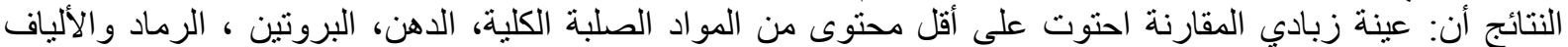

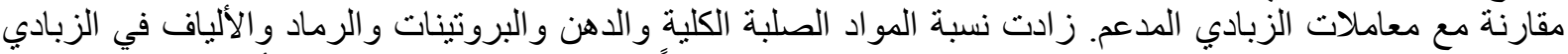

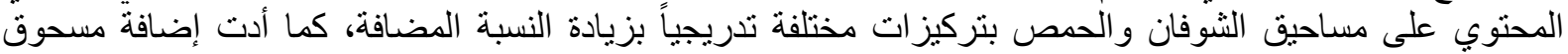

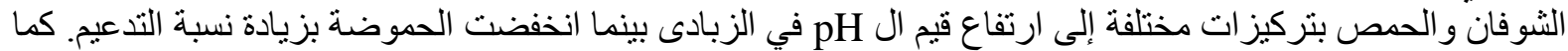

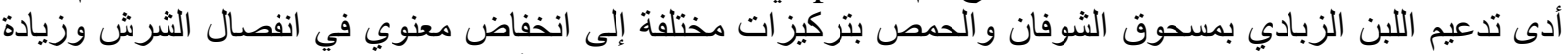

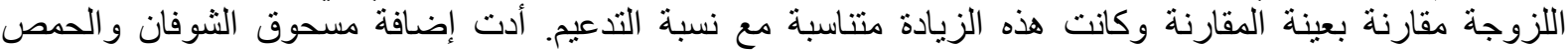

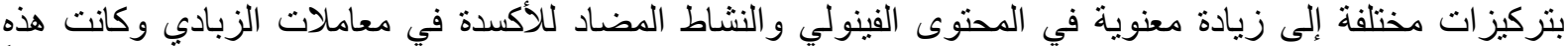

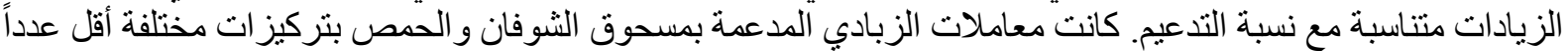

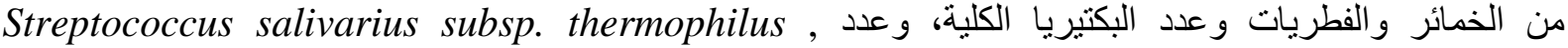
Streptococcus ، واجمالى الخمائر و الفطريات البكتيريالكلية Lactobacillus delbruekii subsp. bulgaricus زsalivarius subsp. thermophilus, Lactobacillus delbruekii subsp. bulgaricus

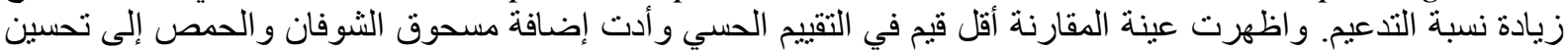

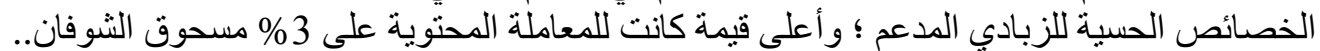

